\title{
Differentiating Induced Pluripotent Stem Cells into Renal Cells: A New Approach to Treat Kidney Diseases
}

\author{
Patrícia de Carvalho Ribeiro $\mathbb{D D}^{1}$ Lucas Felipe Oliveira, ${ }^{2,3}$ Mario Abbud Filho, ${ }^{1,4,5}$ \\ and Heloisa Cristina Caldas ${ }^{1,4}$ \\ ${ }^{1}$ Laboratory of Immunology and Experimental Transplantation-LITEX, Medical School of Sao Jose do Rio Preto, Sao Jose do \\ Rio Preto, Sao Paulo, Brazil \\ ${ }^{2}$ Physiology Division, Natural and Biological Sciences Institute, Triangulo Mineiro Federal University, Uberaba, Minas Gerais, Brazil \\ ${ }^{3}$ National Institute of Science and Technology for Regenerative Medicine, Rio de Janeiro, Rio de Janeiro, Brazil \\ ${ }^{4}$ Kidney Transplant Unit, Hospital de Base, FAMERP/FUNFARME, Sao Jose do Rio Preto, Sao Paulo, Brazil \\ ${ }^{5}$ Urology and Nephrology Institute, Sao Jose Rio Preto, Sao Paulo, Brazil
}

Correspondence should be addressed to Patrícia de Carvalho Ribeiro; patriciarbiomed@gmail.com

Received 28 May 2020; Revised 21 July 2020; Accepted 28 July 2020; Published 7 August 2020

Academic Editor: Nádia K. Gumarães-Souza

Copyright (c) 2020 Patrícia de Carvalho Ribeiro et al. This is an open access article distributed under the Creative Commons Attribution License, which permits unrestricted use, distribution, and reproduction in any medium, provided the original work is properly cited.

\begin{abstract}
Renal disease is a major issue for global public health. Despite some progress in supportive care, the mortality rates among patients with this condition remain alarmingly high. Studies in pursuit of innovative strategies to treat renal diseases, especially stimulating kidney regeneration, have been developed. In this field, stem cell-based therapy has been a promising area. Induced pluripotent stem cell-derived renal cells (iPSC-RCs) represent an interesting source of cells for treating kidney diseases. Advances in regenerative medicine using iPSC-RCs and their application to the kidney are discussed in this review. Furthermore, the way differentiation protocols of induced pluripotent stem cells into renal cells may also be applied for the generation of kidney organoids is also described, contributing to studies in renal development, kidney diseases, and drug toxicity tests. The translation of the differentiation methodologies into animal model studies and the safety and feasibility of renal differentiated cells as a treatment for kidney injury are also highlighted. Although only few studies were published in this field, the results seem promising and support the use of iPSC-RCs as a potential therapy in the future.
\end{abstract}

\section{Introduction}

Kidney disease is a condition characterized by impaired renal function and/or structure $[1,2]$. Its incidence has increased over the years and represents a considerable concern worldwide $[3,4]$. Kidney diseases can be distinguished into acute kidney injury (AKI) and chronic kidney disease (CKD), although intercommunication between these two pathologies has been observed [5].

AKI is characterized by a rapid decline in renal function and excessive renal inflammation, as well as programmed death of resident cells [6-8]. In addition, AKI shows high morbidity and mortality and may progress to CKD [6]. Conversely, $\mathrm{CKD}$ is defined as the irreversible impairment of renal function and/or structure for 3 months or more [9] and its major causes are systemic arterial hypertension and diabetes [10]. Both AKI and CKD may progress to end-stage renal disease (ESRD), a condition with very few effective and specific available therapies, except for supportive care [11]. ESRD reduces quality of life in patients, significantly diminishes life expectancy, and increases health care costs [12].

The high incidence of renal diseases has caused a relentless pursuit of effective therapeutic methods, aiming to slow down or even stop the progress of the disease. Several strategies have been developed over the time, including the first attempt to create an artificial kidney in the 1940s [13], the long-term successful human kidney transplantation from a living donor [14], the introduction of outpatient dialysis in 
the 1960s $[15,16]$, and the discovery of drugs that delay the progression of kidney disease, such as the renin-angiotensinaldosterone system blockers [17]. Nevertheless, further strategies that effectively and ideally remove patients from the transplant queue are still needed. Therefore, the development of new therapeutic strategies is crucial and cellular therapy has emerged as a promising field to achieve this goal.

Adult renal tissue has a limited regeneration capacity after an injury [18]. In this context, there is growing interest in the study of regenerative cell therapy in kidney diseases, especially those involving the use of renal cells derived from induced pluripotent stem cells (iPSC). Since iPSC are immature cells [19] and can originate almost any cell type in the body, differentiation protocols commonly attempt to mimic the embryonic development of the kidneys [20]. Unlike pluripotent stem cells, renal cells have a limited number of divisions and are at a more mature stage of differentiation, representing a safer option for cell therapy [21].

Potential applications of iPSC-RCs are described in the present review, as well as discussions on the advances in regenerative medicine and the safety and feasibility of renal differentiated cells as a treatment for kidney injury.

\section{Embryonic Development of the Mammalian Kidney}

Understanding kidney organogenesis is important to establish a wide range of cell differentiation methodologies. The mammalian kidney originates from the intermediate mesoderm (IM) by the sequential induction of three distinct kidneys: pronephros, mesonephros, and metanephros [22, 23]. During the development process, these structures receive various inductive signals and interactions from the environment in order to become kidneys [22]. The expression of transcription factors PAX2, PAX8, and LHX1 is common to all of them $[24,25]$. The first structure to arise is the pronephros, followed by the mesonephros, both degenerating before birth [23]. However, the metanephros is the last to arise and the only one to persist and form the permanent organ with all its individual functional units-the nephrons $[22,23,26]$.

In the adult kidney, nephrons are originated through reciprocal signal induction between two IM structures: ureteric bud (UB) and metanephric mesenchyme (MM) [22]. The UB is an epithelial side branch of the Wolffian duct [27], and after induction by glial cell line-derived neurotrophic factor (GDNF), produced by the MM, it evolves towards the MM initiating a series of dichotomous branching and leading to the ureteric epithelial tree development, which in turn will originate the collecting ducts in the metanephros [26-28]. At this stage, the GDNF is continued produced by a specific mesenchymal cell population, named cap mesenchyme, which represents nephron progenitor cells (NPCs) and expresses SIX2 transcription factor [29]. The expression of SIX2 is essential for maintaining the NPC in an immature stage, and its cessation is related to the initiation of nephron commitment [30]. Increased levels of the canonical Wnt9b signaling [31], as well as the Notch signaling [30], have been suggested as inductive of a mesenchyme-to-epithelial transi- tion (MET), initiating the differentiation into nephron cells $[27,30]$.

Subsequently, a pretubular aggregate of mesenchyme gives rise to a renal vesicle, which develops a lumen and grows towards the distal end of the ureteric tip to form a contiguous lumen with the ureteric epithelium, enabling the appropriate drainage from the nephron through the collecting ducts [32]. The renal vesicle then elongates into a comma-shaped body that undergoes further morphological alteration into S-shaped body [30]. Following that, a glomerulus formation is initiated with a capillary loop invasion into a region denominated glomerular cleft, located between the primitive podocytes and the proximal tubule, in the Sshaped body [30,33,34]. During the glomerular maturation, the capillary is divided in several loops, endothelial cells became fenestrated, all the capillary structure is enveloped by the glomerular basement membrane, and podocytes extend their foot processes around the endothelial cells [34]. Some of the transcription factors expressed in early stages of podocytes maturation are LMX1B, FOXC2, POD1, FOXD2, and MAFB [35-39].

Regarding other renal development markers, PAX2 and WT1 are expressed at the beginning of the kidney rising and then downregulated [40]. However, they become active again at the final stages of nephron formation. Furthermore, OSR1 transcription factor is expressed in the intermediate mesoderm, while HOX11 is expressed in the metanephric mesenchyme and the coexpression of SIX2, SALL1, WT1, and PAX2 characterizes a NPC [22] (Figure 1).

\section{Pluripotent Stem Cell for Cell-Based Therapy}

Over the past two decades, we have experienced growing interest in the use of stem cells as a therapeutic alternative for regenerating damaged tissues and organs. Stem cells are characterized by a large proliferative ability and potential to differentiate into distinct specialized cells. It is also noteworthy that not all stem cell types possess the same differentiation and therapeutic potentials, since pluripotent stem cells exhibit higher potential than multipotent ones [41].

Pluripotent stem cells are self-renewing, clonogenic, and able to undergo lineage commitment into the three different embryonic germ lines: ectoderm, mesoderm, and endoderm [42]. The most famous source of these cells is human embryos at blastocyst phase, namely, embryonic stem cells (ESCs). However, the use of ESC for cellular therapy is quite complex, considering ethical conflicts concerning manipulation of human embryos and safety concerns related to their immunogenicity, as well as the risk of uncontrolled growth and teratoma formation when administrated in vivo [43].

In an attempt to overcome these issues, a new reprogramming technology has led to the generation of iPSC from somatic cells through the introduction of four factors: Oct4, Sox2, c-Myc, and Klf4 [19]. iPSC share with ESCs many features including pluripotency and high differentiation capacity, representing a promising alternative as a source of pluripotent stem cells without ethical concerns and immunorejection, since they can be generated from patientderived adult cells [41]. 


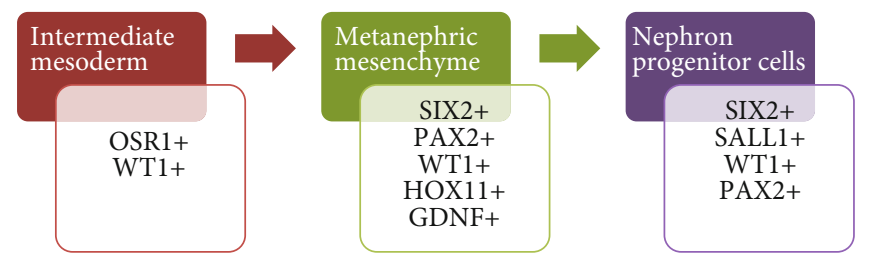

FIGURE 1: Kidney development stages and expression of transcription factors. OSR1 and WT1 are expressed in the intermediate mesoderm; SIX2, PAX2, WT1, HOX11, and GDNF are expressed in the metanephric mesenchyme; coexpression of SIX2, SALL1, WT1, and PAX2 characterizes a NPC.

Although the application of iPSC in regenerative medicine seems to be promising, their use per se in cellular therapy is challenging. Some limitations still persist and include the efficiency of their derivation, the risk of tumor development following transplantation due to their high proliferative potential $[21,44]$, and the use of viral vectors for reprogramming [45], restricting the iPSC application in an immature stage. Therefore, an alternative approach is to differentiate iPSC into a specific cell type before cellular transplantation. Such differentiation protocols enable the management of crucial variables for cell therapy, some of which are cell fate and expansion in culture.

\section{4. iPSC-Derived Renal Cells}

Until recently, renal studies were made only with immortalized kidney cell lines or animal model systems [46]. However, immortalized kidney cells obtained from primary cultures have some limitations, including complications for successful isolation, short-time life periods in culture, and restricted functional and/or morphological characteristics when compared to their native counterparts $[47,48]$. Since the iPSC advent [19], great interest has arisen in studying these cells for several diseases and drug development models. A major advantage in the use of iPSC is that they can be generated from somatic cells, enabling immunocompatible transplantation and development of patient-specific models of disease [44].

In vitro differentiation of iPSC into kidney cells can be achieved by the induction of specific nephrogenic factors. In general, a common step in the differentiation protocols is the use, among other substances, of at least two of these three nephrogenic factors: activin A, retinoic acid (RA), and bone morphogenetic proteins (BMPs). These factors have an important role in the generation of kidney structures and specification of renal progenitor cells during renal development. The use of activin A and RA has been described as capable of generating structures related to kidney development $[49,50]$. The ureteric bud produces activin A during the kidney growth phase, and it is an important nephrogenic factor, inducing the differentiation into metanephric mesenchyme [51]. Similarly, RA is a crucial factor during kidney development and the specification of renal progenitor cells [52]. The blockage of RA action in this phase causes serious abnormalities to the urinary system [53]. BMP7 also plays an important role in the kidney formation, and its genetic ablation results in highly disorganized and undeveloped kidneys, with an expanded interstitium [54]. In this context, diverse differentiation methodologies have been described in the past few years, aiming to transform iPSC into renal cells with similar properties to those observed in vivo (Table 1).

4.1. Differentiation Protocols. Kim and Dressler were the first to use a combination of activin A, BMP7, and RA to differentiate pluripotent stem cells into renal cells [55]. They induced embryoid body (EB) formation and then differentiated mouse embryonic stem cells (ESC) into cells expressing markers for intermediate mesoderm and early derivatives of the metanephric mesenchyme, such as PAX2, WT1, LIM1, GDNF, Cadherin-6, and EYA1. In addition, they injected the resulting cells into a developing kidney and observed their integration into tubules, along with the expression of proximal tubule markers.

Following this work, Morizane et al. [56] have used iPSC for the generation of kidney cells, which expressed SIX2, WT1, PAX2, Nephrin, and KSP (the last one being a tubular specific marker). The authors generated iPSC from mouse fibroblasts and then initiated the differentiation by the induction of embryoid body (EB) formation, followed by cell plating in gelatin-coated dishes. During the entire process, activin, GDNF, and BMP7 or only activin was added to the differentiation media. When the three nephrogenic factors were used, the authors found that the iPSC could differentiate into metanephric mesenchyme cells, while the sole use of activin enables the generation of tubular cells.

In 2012, Song and collaborators described the direct differentiation into renal cells using human iPSC [57]. The iPSC were generated from normal human kidney mesangial cells and induced to differentiate into renal progenitor cells (RPCs). Activin A, BMP7, and RA were used as nephrogenic factors. The protocol was initiated with the EB formation, followed by adherent culture, for 10 days. At the end of the protocol, cells were characterized and they showed the expression of Nephrin, Synaptopodin, PAX2, and WT1, as well as functional properties similar to those observed in podocytes from primary culture. Furthermore, the cells were able to proliferate in vitro and could be maintained up to 3 months. Later, several new studies were published reporting the generation of different types of renal cells and improving the differentiation protocols [58-84] available.

4.2. Kidney Organoids. The evolution on the knowledge related to kidney organogenesis enabled the creation of enhanced methodologies, in special the ones involving $3 \mathrm{D}$ mini-organs, the organoids, which host several kinds of renal 
TABLE 1: Protocols for iPSC differentiation into renal cells.

\begin{tabular}{|c|c|c|c|c|}
\hline Authors & Differentiation factors & $\begin{array}{l}\text { Differentiation } \\
\text { period }\end{array}$ & Starting iPSC type & Induced cell type \\
\hline $\begin{array}{l}\text { Morizane et al. } \\
2009[56]\end{array}$ & Activin A, GDNF, BMP7 & $\begin{array}{l}14 \text { days or } 18 \\
\text { days }\end{array}$ & Murine iPSC & $\begin{array}{l}\text { Tubular cells, metanephric } \\
\text { mesenchyme cells }\end{array}$ \\
\hline $\begin{array}{l}\text { Song et al. } 2012 \\
\text { [57] }\end{array}$ & Activin A, BMP7, and RA & 10 days & Human iPSC & Podocyte-like cells \\
\hline $\begin{array}{l}\text { Mae et al. } 2013 \\
{[58]}\end{array}$ & CHIR99021, Activin A, and BMP7 & $\sim 10$ to 20 days & $\begin{array}{l}\text { OSR1-GFP } \\
\text { human iPSC }\end{array}$ & $\begin{array}{l}\text { Intermediate mesoderm } \\
\text { cells }\end{array}$ \\
\hline $\begin{array}{l}\text { Xia et al. } 2013 \\
{[59]}\end{array}$ & BMP4, FGF2, RA, activin A, and BMP2 & 4 days & Human iPSC & $\begin{array}{l}\text { Ureteric bud kidney } \\
\text { progenitor-like cells }\end{array}$ \\
\hline $\begin{array}{l}\text { Taguchi et al. } \\
2014[60]\end{array}$ & BMP4, activin A, basic FGF, CHIR RA, and FGF9 & 14 days & Human iPSC & $\begin{array}{l}\text { Kidney } \\
\text { organoid-Metanephric } \\
\text { nephron progenitors }\end{array}$ \\
\hline $\begin{array}{l}\text { Araoka et al. } \\
2014[61]\end{array}$ & CHIR99021 and AM580 or TTNPB & 5 days & $\begin{array}{l}\text { Human iPSC and } \\
\text { OSR1-GFP } \\
\text { human iPSC }\end{array}$ & $\begin{array}{l}\text { Intermediate mesoderm } \\
\text { cells }\end{array}$ \\
\hline $\begin{array}{l}\text { Lam et al. } 2014 \\
\text { [62] }\end{array}$ & CHIR99021, FGF2, RA, FGF9, and activin A & 9 days & Human iPSC & $\begin{array}{l}\text { Intermediate mesoderm } \\
\text { cells }\end{array}$ \\
\hline $\begin{array}{l}\text { Kang \& Han } \\
2014[63]\end{array}$ & Activin A, Wnt3a, BMP4, FGF2, RA, BMP7 & 26 days & Human iPSC & Nephron progenitor cells \\
\hline $\begin{array}{l}\text { Imberti et al. } \\
2015 \text { [64] }\end{array}$ & $\begin{array}{l}\text { RA, RhoA inhibitor and PI3K inhibitor, activin A, } \\
\text { FGF2, BMP7, and GDNF }\end{array}$ & 19 days & Human iPSC & Renal progenitor cells \\
\hline $\begin{array}{l}\text { Toyohara et al. } \\
2015 \text { [65] }\end{array}$ & $\begin{array}{c}\text { Activin A, CHIR, BMP7, TTNPB, TGF- } \beta 1 \text {, and } \\
\text { DMH1 }\end{array}$ & 28 days & Human iPSC & Renal progenitor cells \\
\hline $\begin{array}{l}\text { Li et al. } 2015 \\
{[66]}\end{array}$ & $\begin{array}{c}\text { RA, BMP7, activin A, renal epithelial cell growth } \\
\text { medium alone }\end{array}$ & 10 days & Mouse iPSC & Renal progenitor cells \\
\hline $\begin{array}{l}\text { Kandasamy } \\
\text { et al. } 2015 \text { [67] }\end{array}$ & $\begin{array}{l}\text { Renal epithelial growth medium, Rho kinase, BMP2, } \\
\text { and BMP7 }\end{array}$ & 8 days & Human iPSC & Proximal tubular-like cells \\
\hline $\begin{array}{l}\text { Takasato et al. } \\
2015[68,69]\end{array}$ & CHIR, FGF9, heparin & 25 days & Human iPSC & $\begin{array}{l}\text { Kidney organoid-nephron } \\
\text { segment cells }\end{array}$ \\
\hline $\begin{array}{l}\text { Morizane et al. } \\
2015[70]\end{array}$ & FGF2, CHIR, Noggin, activin A, and FGF9 & $\begin{array}{l}9 \text { days (NPCs) } \\
21-35 \text { days } \\
\text { (organoids) }\end{array}$ & Human iPSC & $\begin{array}{l}\text { Kidney organoid-nephron } \\
\text { progenitor cells and } \\
\text { nephron epithelia }\end{array}$ \\
\hline $\begin{array}{l}\text { Freedman et al. } \\
2015[71]\end{array}$ & CHIR and B27 & 16-23 days & Human iPSC & $\begin{array}{l}\text { Kidney organoid-nephron } \\
\text { segment cells }\end{array}$ \\
\hline $\begin{array}{l}\text { Ciampi et al. } \\
2016[72]\end{array}$ & $\begin{array}{l}\mathrm{N} 2 \text { and B27 supplements, CP21R7 (Roche), BMP4, } \\
\text { retinoic acid, BMP7, FGF9, vitamin D3 }\end{array}$ & 13 days & Human iPSC & Podocyte-like cells \\
\hline $\begin{array}{l}\text { Musah et al. } \\
2017 \text { [73] }\end{array}$ & Activin A, CHIR, BMP7, VEGF, and retinoic acid & 26 days & Human iPSC & Podocyte-like cells \\
\hline $\begin{array}{l}\text { Taguchi \& } \\
\text { Nishinakamura } \\
2017[74]\end{array}$ & $\begin{array}{l}\text { Activin, Bmp4, CHIR, FGF9, FGF1, GDNF, } \\
\text { LDN193189, SB431542, retinoic acid, and B27 }\end{array}$ & 12.5 days & Human iPSC & Ureteric bud-like cells \\
\hline $\begin{array}{l}\text { Wu et al. } 2018 \\
{[75]}\end{array}$ & $\begin{array}{c}\text { CHIR, FGF9, heparin, Noggin, activin, and NTRK2 } \\
\text { inhibitor K252a }\end{array}$ & $25-26$ days & Human iPSC & $\begin{array}{l}\text { Kidney organoid-nephron } \\
\text { progenitor cells }\end{array}$ \\
\hline $\begin{array}{l}\text { Przepiorski et al. } \\
2018 \text { [76] }\end{array}$ & CHIR and KnockOut Serum Replacement (KOSR) & 14-26 days & Human iPSC & $\begin{array}{l}\text { Kidney organoid-nephron } \\
\text { progenitor cells }\end{array}$ \\
\hline $\begin{array}{l}\text { Rauch et al. } \\
2018 \text { [77] }\end{array}$ & Activin A, BMP7, and retinoic acid & 10 days & Human iPSC & Podocyte-like cells \\
\hline $\begin{array}{l}\text { Mae et al. } 2018 \\
{[78]}\end{array}$ & $\begin{array}{l}\text { Activin A, CHIR, BMP4, LDN193189, A83-01, } \\
\text { retinoic acid, PD0325901, FGF8, TTNPB, GDNF, } \\
\text { FGF1, thiazovivin }\end{array}$ & 15 days & Human iPSC & Wolffian duct cells \\
\hline $\begin{array}{l}\text { Qian et al. } 2019 \\
\text { [79] }\end{array}$ & CHIR and B27 & 16 days & Human iPSC & Podocyte-like cells \\
\hline $\begin{array}{l}\text { Hariharan et al. } \\
2019 \text { [80] }\end{array}$ & $\begin{array}{c}\text { Activin A, BMP4, retinoic acid, GDNF, HGF, } \\
\text { REGM, FGF2, and BMP7 }\end{array}$ & 6 - 14 days & Human iPSC & $\begin{array}{l}\text { Renal progenitor cell- } \\
\text { multiple nephronal cell }\end{array}$ \\
\hline
\end{tabular}


TABle 1: Continued.

\begin{tabular}{lcccc}
\hline Authors & Differentiation factors & $\begin{array}{c}\text { Differentiation } \\
\text { period }\end{array}$ & Starting iPSC type & Induced cell type \\
\hline $\begin{array}{l}\text { Ahmadi et al. } \\
2019[81]\end{array}$ & CHIR, PD032590, activin A, TTNPB, BMP7, LIF, & 22 days & Mouse iPSC & Podocyte-like cells \\
$\begin{array}{l}\text { Garreta et al. } \\
2019[82]\end{array}$ & CHIR, FGF9, heparin, activin A & 21 days & Human iPSC & $\begin{array}{c}\text { Kidney organoid-nephron } \\
\text { segment cells }\end{array}$ \\
\hline
\end{tabular}

cells [60]. Takasato et al. $[68,69]$ have developed a 3D differentiation protocol by which kidney organoids were generated. Using CHIR, FGF9, and heparin in a series of methodological steps for 25 days, the authors described the formation of a 3D structure, which consisted of multiple nephron segment cells, expressing markers for glomerulus $\left(\mathrm{WT}^{+}{ }^{+}\right.$cells), early distal tubule (GATA3 ${ }^{-} \mathrm{LTL}^{-} \mathrm{ECAD}^{+}$ cells), early proximal tubule $\left(\mathrm{LTL}^{+} \mathrm{ECAD}^{-}\right.$cells), and collecting duct $\left(\mathrm{GATA}^{+} \mathrm{ECAD1}^{+}\right.$cells). Renal structures observed during the differentiation protocol resembled in vivo kidney tissue organization, and each organoid comprised a substantial size with more than 500 nephrons.

Morizane and collaborators [70] also described a kidney organoid generation, mainly through CHIR and FGF9 induction in a 3D culture. The authors first differentiated human iPSC into primitive streak cells, following induction into posterior intermediate mesoderm and nephron progenitor cells. These cells were transferred to a 3D culture and treated with CHIR and FGF9 and by day 21; the renal organoids were spontaneously organized in elongated epithelial nephron structures expressing several nephron markers. These structures expressed nephron markers in a contiguous arrangement, including loops of Henle (E-cadherin $(\mathrm{CDH1})^{+}$ uromodulin (UMOD) ${ }^{+} \mathrm{BRN1}^{+} \mathrm{AQP1}^{+}$), distal convoluted tubules $\left(\mathrm{CDH}^{+} \mathrm{UMOD}^{-}\right)$, glomerular podocytes $\left(\mathrm{NPHS}^{+-}\right.$ $\mathrm{PODXL}^{+} \mathrm{WT}^{+}{ }^{+}$), and proximal tubules $\left(\mathrm{LTL}^{+} \mathrm{AQP} 1^{+}\right)$.

Over the past few years, several other protocols involving kidney organoid generation $[71,75,76,82]$ were also described, enabling the use of such differentiated cells for experimental models in kidney disease.

\section{5. iPSC-Derived Renal Cells as Cell Therapy for Kidney Diseases}

The ability to self-renew and differentiate makes stem cells a promising strategy for regenerating damaged kidneys. Our group has recently published a work [44] studying the therapeutic potential of iPSC in a CKD model in rats (the $5 / 6$ model). Although iPSC ameliorated CKD rats, they also generated Wilms' tumors, justifying the essential step of differentiating iPSC into renal cells prior to their transplantation into kidney disease models [21, 44].

Few reports have addressed the regenerative potential of iPSC-derived renal cells in kidney diseases (Table 2). Imberti et al. [64] described the generation of renal progenitor cells from human iPSC and studied their therapeutic potential in a mouse model of AKI. Intravenously infused RPCs integrated into mouse renal tissue as early as $24 \mathrm{~h}$ after transplan- tation, especially into tubuli. Results showed a reduction of blood urea nitrogen (BUN) levels and improved renal histology in mice when compared to the control group.

Toyohara et al. [65] have injected OSR $1^{+}$SIX2 ${ }^{+}$RPCs into the renal subcapsule of induced AKI mice and observed that although the cells did not differentiate into tubular structures, kidney function was improved in the treated animals. In addition, histological analysis demonstrated a significant reduction in renal parenchyma damage. Similarly, Li et al. [66] have transplanted RPCs into an ischemia/reperfusioninduced AKI model in rats and observed improved renal function and histological aspects in the treated group.

More recently, Hoshina et al. [83] studied hiPSC-derived RPCs $\left(\mathrm{CD} 9^{-} \mathrm{CD} 140 \mathrm{a}^{+} \mathrm{CD} 140 \mathrm{~b}^{+} \mathrm{CD} 271^{+}\right.$cells) as a therapy for AKI. Cells were injected into renal subcapsules after the induction of AKI in a mouse model. The authors described improved renal function and reduced tissue damage, indicated by decreased fibrosis, tubular dilatation, and loss of tubular borders. Ahmadi et al. [81] also studied the potential of renal cells in kidney disease, specifically using iPSCderived podocytes in a mouse model of membranous nephropathy. As early as 10 days after the cell transplantation, proteinuria was significantly decreased in the treated animals and there was also reduction in the urine albumin/creatinine ratio, indicating the benefits of using mature renal cells (iPSC-podocyte) as cell therapy.

\section{Future Perspectives}

A nephron is a complex structure, composed of multiple varieties of cells [84]. Therefore, addressing which one should be transplanted for treating specific kidney injuries remains a challenge. However, it is expected that the transplantation of kidney progenitors enables the final cell differentiation into the tissue and provides a source of several types of cells, which can be used for renal regeneration and improvement of kidney function [85] (Figure 2).

iPSC represent a valuable choice for cell therapy, considering their ability to generate renal cells at their more primitive lineage stage. Such cells may then be employed for therapeutic proposes, differentiated into a mature cell, or even be used for repopulating decellularized native kidney $[86,87]$. The advance in the understanding of the kidney development has provided the refinement of differentiation methodologies leading to improved cost-effective protocols and generation of more types of cells and even more complex and organized structures [88, 89]. 3D 
TABLE 2: Published studies involving iPSC-derived renal cells in kidney diseases.

\begin{tabular}{lcc}
\hline Authors & iPSC-derived cell type & Kidney disease type \\
\hline Imberti et al. $2015[64]$ & Renal progenitor cell & Cisplatin-induced AKI \\
Toyohara et al. $2015[65]$ & Renal progenitor cell & Ischemia/reperfusion-induced AKI \\
Li et al. $2015[66]$ & Renal progenitor cell & Ischemia/reperfusion-induced AKI \\
Hoshina et al. 2018 [83] & Renal progenitor cell & Ischemia/reperfusion-induced AKI \\
Ahmadi et al. $2019[81]$ & Podocytes & Membranous nephropathy \\
\hline
\end{tabular}

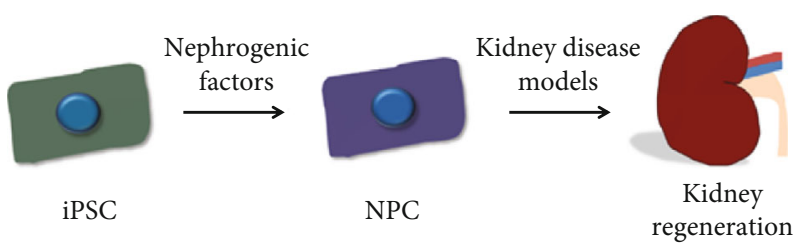

Figure 2: iPSC-derived renal cells in kidney diseases. iPSC: induced pluripotent stem cells; NPC: nephron progenitor cell.

conformation culture, associated with specific growth factors, is aimed at mimicking the developmental stages and provides generation of organoids, with a wide range of cell types that are also self-organized in organ-specific structures, resembling their native counterparts [90].

The development of kidney organoids allows their use for regenerative medicine as a source of several types of renal cells (from RPCs to mature podocytes or tubular cells), which could be applied for cell therapy [91]. In addition, such organoids may be used for studying renal embryonic development and diseases, as well as for testing drug toxicity and, therefore, providing a valuable tool for improving in vitro scale, structure, and functional maturation of the kidney in the future [92-94].

Although the studies underlying the use of iPSC-derived renal cells in kidney diseases have promising results, only a few were published and further investigation on whether these cells could effectively be applicable as a treatment or not is needed. Studies in this direction may provide a better understanding of the action mechanisms of renal cells in kidney diseases and their efficacy and safety, as well as the possibility to translate these discoveries from bench to bedside. Further studies are necessary to address the use of iPSCderived renal cells in CKD. Such cells may represent a promising strategy to slow down the progression of disease and regenerate the damaged tissue.

\section{Conclusions}

The development of innovative iPSC differentiation protocols into renal cells and the advanced knowledge in kidney development enable the emergence of new studies focused on the treatment of kidney diseases. Such studies demonstrate the therapeutic potential of differentiated renal cells, supporting their promising use as cell therapy. Long-term studies are necessary to address the beneficial effects and safety of iPSC-derived renal cells.

\section{Data Availability}

The data supporting this review are from previously reported studies and datasets, which have been cited in the manuscript.

\section{Conflicts of Interest}

The authors declare no conflicts of interest.

\section{Acknowledgments}

This work was financially supported by the Coordination for the Improvement of Higher Education Personnel (CAPES (Coordenação de Aperfeiçoamento de Pessoal de Nível Superior)), as a PhD fellowship to Patrícia de Carvalho Ribeiro.

\section{References}

[1] S. Negi, D. Koreeda, S. Kobayashi et al., "Acute kidney injury: epidemiology, outcomes, complications, and therapeutic strategies," Seminars in Dialysis, vol. 31, no. 5, pp. 519-527, 2018.

[2] R. J. Glassock, D. G. Warnock, and P. Delanaye, "The global burden of chronic kidney disease: estimates, variability and pitfalls," Nature Reviews Nephrology, vol. 13, no. 2, pp. 104$114,2017$.

[3] GBD 2016 Disease and Injury Incidence and Prevalence Collaborators, "Global, regional, and national incidence, prevalence, and years lived with disability for 328 diseases and injuries for 195 countries, 1990-2016: a systematic analysis for the Global Burden of Disease Study 2016," Lancet, vol. 390, pp. 1211-1259, 2017.

[4] A. Levin, M. Tonelli, J. Bonventre et al., "Global kidney health 2017 and beyond: a roadmap for closing gaps in care, research, and policy," Lancet, vol. 390, no. 10105, pp. 1888-1917, 2017.

[5] D. A. Ferenbach and J. V. Bonventre, "Acute kidney injury and chronic kidney disease: from the laboratory to the clinic," Nephrol Ther, vol. 12, pp. S41-S48, 2016.

[6] M. Al-Jaghbeer, D. Dealmeida, A. Bilderback, R. Ambrosino, and J. A. Kellum, "Clinical decision support for in-hospital AKI," Journal of the American Society of Nephrology, vol. 29, no. 2, pp. 654-660, 2018.

[7] A. Khwaja, "KDIGO clinical practice guidelines for acute kidney injury," Nephron. Clinical Practice, vol. 120, no. 4, pp. c179-c184, 2012.

[8] E. A. J. Hoste, S. M. Bagshaw, R. Bellomo et al., "Epidemiology of acute kidney injury in critically ill patients: the multinational AKI-EPI study," Intensive Care Medicine, vol. 41, no. 8, pp. 1411-1423, 2015. 
[9] Kidney Disease: Improving Global Outcomes (KDIGO) CKD Work Group, KDIGO, "Clinical practice guideline for the evaluation and management of chronic kidney disease," Kidney International Supplements 2013, vol. 3, no. 1, pp. 1-150, 2012.

[10] T. K. Chen, D. H. Knicely, and M. E. Grams, "Chronic kidney disease diagnosis and management," JAMA, vol. 322, no. 13, pp. 1294-1304, 2019.

[11] T. Liyanage, T. Ninomiya, V. Jha et al., "Worldwide access to treatment for end-stage kidney disease: a systematic review," Lancet, vol. 385, no. 9981, pp. 1975-1982, 2015.

[12] M. Kohlová, C. G. Amorim, A. Araújo, A. Santos-Silva, P. Solich, and M. C. B. S. M. Montenegro, "The biocompatibility and bioactivity of hemodialysis membranes: their impact in end-stage renal disease," Journal of Artificial Organs, vol. 22, no. 1, pp. 14-28, 2019.

[13] E. A. Friedman, "Willem Johan "Pim" Kolff," Dialysis \& Transplantation, vol. 38, no. 5, pp. 180-182, 2009.

[14] J. P. Merrill, H. Harrison, J. Murray, and W. R. Guild, "Successful homotransplantation of the kidney in an identical twin," Transactions of the American Clinical and Climatological Association, vol. 67, pp. 167-173, 1956.

[15] B. H. Scribner, J. E. Z. Caner, R. Buri, and W. Quinton, “The technique of continuous hemodialysis," Transactions - American Society for Artificial Internal Organs, vol. 6, pp. 88-103, 1960.

[16] W. Quinton, D. Dillard, and B. H. Scribner, "Cannulation of blood vessels for prolonged hemodialysis," Transactions - American Society for Artificial Internal Organs, vol. 6, pp. 104-113, 1960.

[17] B. M. Brenner, M. E. Cooper, D. de Zeeuw et al., "Effects of losartan on renal and cardiovascular outcomes in patients with type 2 diabetes and nephropathy," The New England Journal of Medicine, vol. 345, no. 12, pp. 861-869, 2001.

[18] N. V. Andrianova, M. I. Buyan, L. D. Zorova et al., "Kidney cells regeneration: dedifferentiation of tubular epithelium, resident stem cells and possible niches for renal progenitors," International Journal of Molecular Sciences, vol. 20, no. 24, p. 6326, 2019.

[19] K. Takahashi and S. Yamanaka, "Induction of pluripotent stem cells from mouse embryonic and adult fibroblast cultures by defined factors," Cell, vol. 126, no. 4, pp. 663676, 2006.

[20] P. Srivastava and K. A. Kilian, "Micro-engineered models of development using induced pluripotent stem cells," Frontiers in Bioengineering and Biotechnology, vol. 7, p. 357, 2019.

[21] M. H. Little and P. Kairath, "Regenerative medicine in kidney disease," Kidney International, vol. 90, no. 2, pp. 289-299, 2016.

[22] R. Morizane and A. Q. Lam, "Directed differentiation of pluripotent stem cells into kidney," Biomarker Insights, vol. 10, Supplement 1, pp. 147-152, 2015.

[23] M. H. Little and A. P. McMahon, "Mammalian kidney development: principles, progress, and projections," Cold Spring Harbor Perspectives in Biology, vol. 4, no. 5, 2012.

[24] M. Bouchard, A. Souabni, M. Mandler, A. Neubuser, and M. Busslinger, "Nephric lineage specification by Pax 2 and Pax 8," Genes \& Development, vol. 16, no. 22, pp. 2958-2970, 2002.

[25] K. M. Georgas, H. S. Chiu, E. Lesieur, B. A. Rumballe, and M. H. Little, "Expression of metanephric nephron-patterning genes in differentiating mesonephric tubules," Developmental Dynamics, vol. 240, no. 6, pp. 1600-1612, 2011.

[26] M. H. Little, A. N. Combes, and M. Takasato, "Understanding kidney morphogenesis to guide renal tissue regeneration," Nature Reviews Nephrology, vol. 12, no. 10, pp. 624-635, 2016.

[27] M. H. Little, S. V. Kumar, and T. Forbes, "Recapitulating kidney development: progress and challenges," Seminars in Cell \& Developmental Biology, vol. 91, pp. 153-168, 2019.

[28] F. Costantini and R. Kopan, "Patterning a complex organ: branching morphogenesis and nephron segmentation in kidney development," Developmental Cell, vol. 18, no. 5, pp. 698-712, 2010.

[29] A. Kobayashi, M. T. Valerius, J. W. Mugford et al., "Six 2 defines and regulates a multipotent self-renewing nephron progenitor population throughout mammalian kidney development," Cell Stem Cell, vol. 3, no. 2, pp. 169-181, 2008.

[30] M. Mukherjee, E. Fogarty, M. Janga, and K. Surendran, "Notch signaling in kidney development, maintenance, and disease," Biomolecules, vol. 9, no. 11, p. 692, 2019.

[31] C. M. Karner, A. Das, Z. Ma et al., "Canonical Wnt9b signaling balances progenitor cell expansion and differentiation during kidney development," Development, vol. 138, no. 7, pp. 1247-1257, 2011.

[32] K. Georgas, B. Rumballe, M. T. Valerius et al., "Analysis of early nephron patterning reveals a role for distal RV proliferation in fusion to the ureteric tip via a cap mesenchyme-derived connecting segment," Developmental Biology, vol. 332, no. 2, pp. 273-286, 2009.

[33] M. Nagata, "Glomerulogenesis and the role of endothelium," Current Opinion in Nephrology and Hypertension, vol. 27, no. 3, pp. 159-164, 2018.

[34] S. E. Quaggin and J. A. Kreidberg, "Development of the renal glomerulus: good neighbors and good fences," Development, vol. 135, no. 4, pp. 609-620, 2008.

[35] S. D. Dreyer, G. Zhou, A. Baldini et al., "Mutations in LMX1B cause abnormal skeletal patterning and renal dysplasia in nail patella syndrome," Nature Genetics, vol. 19, no. 1, pp. 47-50, 1998.

[36] M. Takemoto, L. He, J. Norlin et al., "Large-scale identification of genes implicated in kidney glomerulus development and function," The EMBO Journal, vol. 25, no. 5, pp. 1160-1174, 2006.

[37] S. E. Quaggin, G. B. Vanden Heuvel, and P. Igarashi, "Pod-1, a mesoderm-specific basic-helix-loop-helix protein expressed in mesenchymal and glomerular epithelial cells in the developing kidney," Mechanisms of Development, vol. 71, no. 1-2, pp. 37-48, 1998.

[38] T. Kume, K. Deng, and B. L. Hogan, "Minimal phenotype of mice homozygous for a null mutation in the forkhead/winged helix gene, Mf2," Molecular and Cellular Biology, vol. 20, no. 4, pp. 1419-1425, 2000.

[39] V. S. Sadl, F. Jin, J. Yu et al., "The Mouse Kreisler(Krml1 / $M a f B)$ Segmentation Gene Is Required for Differentiation of Glomerular Visceral Epithelial Cells," Developmental Biology, vol. 249, no. 1, pp. 16-29, 2002.

[40] K. Georgas, B. Rumballe, L. Wilkinson et al., "Use of dual section mRNA in situ hybridisation/immunohistochemistry to clarify gene expression patterns during the early stages of nephron development in the embryo and in the mature nephron of the adult mouse kidney," Histochemistry and Cell Biology, vol. 130, no. 5, pp. 927-942, 2008. 
[41] C. Rota, M. Morigi, and B. Imberti, "Stem cell therapies in kidney diseases: progress and challenges," International Journal of Molecular Sciences, vol. 20, no. 11, p. 2790, 2019.

[42] M. J. Evans and M. H. Kaufman, "Establishment in culture of pluripotential cells from mouse embryos," Nature, vol. 292, no. 5819, pp. 154-156, 1981.

[43] M. Ohnuki and K. Takahashi, "Present and future challenges of induced pluripotent stem cells," Philosophical Transactions of the Royal Society of London. Series B, Biological Sciences, vol. 370, no. 1680, p. 20140367, 2015.

[44] H. C. Caldas, F. H. Lojudice, C. Dias et al., "Induced pluripotent stem cells reduce progression of experimental chronic kidney disease but develop Wilms' tumors," Stem Cells International, vol. 2017, Article ID 7428316, 11 pages, 2017.

[45] J. Lewandowski and M. Kurpisz, "Techniques of human embryonic stem cell and induced pluripotent stem cell derivation," Archivum Immunologiae et Therapiae Experimentalis, vol. 64 , no. 5, pp. 349-370, 2016.

[46] M. M. Kaminski, J. Tosic, R. Pichler, S. J. Arnold, and S. S. Lienkamp, "Engineering kidney cells: reprogramming and directed differentiation to renal tissues," Cell and Tissue Research, vol. 369, no. 1, pp. 185-197, 2017.

[47] P. C. Baer, U. W. Tunn, G. Nunez, J. E. Scherberich, and H. Geiger, "Transdifferentiation of distal but not proximal tubular epithelial cells from human kidney in culture," Experimental Nephrology, vol. 7, no. 4, pp. 306-313, 1999.

[48] S. E. Jenkinson, G. W. Chung, E. Loonvan, N. S. Bakar, A. M. Dalzell, and C. D. Brown, "The limitations of renal epithelial cell line HK-2 as a model of drug transporter expression and function in the proximal tubule," Pflügers Archiv, vol. 464, no. 6, pp. 601-611, 2012.

[49] N. Moriya, H. Uchiyama, and M. Asashima, "Induction of pronephric tubules by activin and retinoic acid in presumptive ectoderm of Xenopus laevis," Development, Growth and Differentiation, vol. 35, no. 2, pp. 123-128, 1993.

[50] K. Osafune, R. Nishinakamura, S. Komazaki, and M. Asashima, "In vitro induction of the pronephric duct in Xenopus explants," Development, Growth \& Differentiation, vol. 44, no. 2, pp. 161-167, 2002.

[51] A. Maeshima, S. Yamashita, K. Maeshima, I. Kojima, and Y. Nojima, "Activin a produced by ureteric bud is a differentiation factor for metanephric mesenchyme," Journal of the American Society of Nephrology, vol. 14, no. 6, pp. 15231534, 2003.

[52] J. Cartry, M. Nichane, V. Ribes et al., "Retinoic acid signalling is required for specification of pronephric cell fate," Developmental Biology, vol. 299, no. 1, pp. 35-51, 2006.

[53] C. Mendelsohn, D. Lohnes, D. Décimo et al., "Function of the retinoic acid receptors (RARs) during development (II). Multiple abnormalities at various stages of organogenesis in RAR double mutants," Development, vol. 120, no. 10, pp. 27492771, 1994.

[54] S. R. Manson, P. F. Austin, Q. Guo, and K. H. Moore, "BMP-7 signaling and its critical roles in kidney development, the responses to renal injury, and chronic kidney disease," Vitamins and Hormones, vol. 99, pp. 91-144, 2015.

[55] D. Kim and G. R. Dressler, "Nephrogenic factors promote differentiation of mouse embryonic stem cells into renal epithelia," Journal of the American Society of Nephrology, vol. 16, no. 12, pp. 3527-3534, 2005.
[56] R. Morizane, T. Monkawa, and H. Itoh, "Differentiation of murine embryonic stem and induced pluripotent stem cells to renal lineage in vitro," Biochemical and Biophysical Research Communications, vol. 390, no. 4, pp. 1334-1339, 2009.

[57] B. Song, A. M. Smink, C. V. Jones et al., "The directed differentiation of human iPS cells into kidney podocytes," PLoS One, vol. 7, no. 9, article e46453, 2012.

[58] S.-I. Mae, A. Shono, F. Shiota et al., "Monitoring and robust induction of nephrogenic intermediate mesoderm from human pluripotent stem cells," Nature Communications, vol. 4, no. 1, 2013.

[59] Y. Xia, E. Nivet, I. Sancho-Martinez et al., "Directed differentiation of human pluripotent cells to ureteric bud kidney progenitor-like cells," Nature Cell Biology, vol. 15, no. 12, pp. 1507-1515, 2013.

[60] A. Taguchi, Y. Kaku, T. Ohmori et al., "Redefining the in vivo origin of metanephric nephron progenitors enables generation of complex kidney structures from pluripotent stem cells," Cell Stem Cell, vol. 14, no. 1, pp. 53-67, 2014.

[61] T. Araoka, S.-I. Mae, Y. Kurose et al., "Efficient and rapid induction of human iPSCs/ESCs into nephrogenic intermediate mesoderm using small molecule-based differentiation methods," PLoS One, vol. 9, no. 1, article e84881, 2014.

[62] A. Q. Lam, B. S. Freedman, R. Morizane, P. H. Lerou, M. T. Valerius, and J. V. Bonventre, "Rapid and efficient differentiation of human pluripotent stem cells into intermediate mesoderm that forms tubules expressing kidney proximal tubular markers," J Am Soc Nephrol, vol. 25, no. 6, pp. 1211-1225, 2014.

[63] M. Kang and Y. M. Han, "Differentiation of human pluripotent stem cells into nephron progenitor cells in a serum and feeder free system," PLoS One, vol. 9, no. 4, article e94888, 2014.

[64] B. Imberti, S. Tomasoni, O. Ciampi et al., "Renal progenitors derived from human iPSCs engraft and restore function in a mouse model of acute kidney injury," Scientific Reports, vol. 5, no. 1, 2015.

[65] T. Toyohara, S. I. Mae, S. I. Sueta et al., "Cell therapy using human induced pluripotent stem cell-derived renal progenitors ameliorates acute kidney injury in mice," Stem Cells Translational Medicine, vol. 4, no. 9, pp. 980-992, 2015.

[66] Q. Li, S. F. Tian, Y. Guo et al., "Transplantation of induced pluripotent stem cell-derived renal stem cells improved acute kidney injury," Cell \& Bioscience, vol. 5, no. 1, 2015.

[67] K. Kandasamy, J. K. C. Chuah, R. Su et al., "Prediction of druginduced nephrotoxicity and injury mechanisms with human induced pluripotent stem cell-derived cells and machine," Scientific Reports, vol. 5, p. 12337, 2017.

[68] M. Takasato, P. X. Er, H. S. Chiu et al., "Kidney organoids from human iPS cells contain multiple lineages and model human nephrogenesis," Nature, vol. 526, no. 7574, pp. 564$568,2015$.

[69] M. Takasato, P. X. Er, H. S. Chiu, and M. H. Little, "Generation of kidney organoids from human pluripotent stem cells," Nature Protocols, vol. 11, no. 9, pp. 1681-1692, 2016.

[70] R. Morizane, A. Q. Lam, B. S. Freedman, S. Kishi, M. T. Valerius, and J. V. Bonventre, "Nephron organoids derived from human pluripotent stem cells model kidney development and injury," Nature Biotechnology, vol. 33, no. 11, pp. 11931200, 2015.

[71] B. S. Freedman, C. R. Brooks, A. Q. Lam et al., "Modelling kidney disease with CRISPR-mutant kidney organoids derived 
from human pluripotent epiblast spheroids," Nature Communications, vol. 6, no. 1, 2015.

[72] O. Ciampi, R. Iacone, L. Longaretti et al., "Generation of functional podocytes from human induced pluripotent stem cells," Stem Cell Research, vol. 17, no. 1, pp. 130-139, 2016.

[73] S. Musah, A. Mammoto, T. C. Ferrante et al., "Mature induced-pluripotent-stem-cell-derived human podocytes reconstitute kidney glomerular-capillary-wall function on a chip," Nature Biomedical Engineering, vol. 1, no. 5, 2017.

[74] A. Taguchi and R. Nishinakamura, "Higher-order kidney organogenesis from pluripotent stem cells," Cell Stem Cell, vol. 21, no. 6, pp. 730-746.e6, 2017.

[75] H. Wu, K. Uchimura, E. L. Donnelly, Y. Kirita, S. A. Morris, and B. D. Humphreys, "Comparative analysis and refinement of human PSC-derived kidney organoid differentiation with single-cell transcriptomics," Cell Stem Cell, vol. 23, no. 6, pp. 869-881.e8, 2018.

[76] A. Przepiorski, V. Sander, T. Tran et al., “A simple bioreactorbased method to generate kidney organoids from pluripotent stem cells," Stem Cell Reports, vol. 11, no. 2, pp. 470-484, 2018.

[77] C. Rauch, E. Feifel, G. Kern et al., "Differentiation of human iPSCs into functional podocytes," PLoS One, vol. 13, no. 9, article e0203869, 2018.

[78] S.-I. Mae, M. Ryosaka, T. Toyoda et al., "Generation of branching ureteric bud tissues from human pluripotent stem cells," Biochemical and Biophysical Research Communications, vol. 495, no. 1, pp. 954-961, 2018.

[79] T. Qian, S. E. Hernday, X. Bao et al., "Directed differentiation of human pluripotent stem cells to podocytes under defined conditions," Scientific Reports, vol. 9, no. 1, p. 2765, 2019.

[80] K. Hariharan, H. Stachelscheid, B. Rossbach et al., "Parallel generation of easily selectable multiple nephronal cell types from human pluripotent stem cells," Cellular and Molecular Life Sciences, vol. 76, no. 1, pp. 179-192, 2019.

[81] A. Ahmadi, R. Moghadasali, V. Ezzatizadeh et al., "Transplantation of mouse induced pluripotent stem cell-derived podocytes in a mouse model of membranous nephropathy attenuates proteinuria," Scientific Reports, vol. 9, no. 1, p. 15467, 2019.

[82] E. Garreta, P. Prado, C. Tarantino et al., "Fine tuning the extracellular environment accelerates the derivation of kidney organoids from human pluripotent stem cells," Nature Materials, vol. 18, no. 4, pp. 397-405, 2019.

[83] A. Hoshina, T. Kawamoto, S. I. Sueta et al., "Development of new method to enrich human iPSC-derived renal progenitors using cell surface markers," Scientific Reports, vol. 8, no. 1, 2018.

[84] L. L. O'Brien and A. P. McMahon, "Induction and patterning of the metanephric nephron," Seminars in Cell \& Developmental Biology, vol. 36, pp. 31-38, 2014.

[85] B. Bussolati and G. Camussi, "Therapeutic use of human renal progenitor cells for kidney regeneration," Nature Reviews Nephrology, vol. 11, no. 12, pp. 695-706, 2015.

[86] C. Du, K. Narayanan, M. F. Leong et al., "Functional kidney bioengineering with pluripotent stem-cell-derived renal progenitor cells and decellularized kidney scaffolds," Advanced Healthcare Materials, vol. 5, no. 16, pp. 2080-2091, 2016.

[87] J. J. Song, J. P. Guyette, S. E. Gilpin, G. Gonzalez, J. P. Vacanti, and H. C. Ott, "Regeneration and experimental orthotopic transplantation of a bioengineered kidney," Nature Medicine, vol. 19, no. 5, pp. 646-651, 2013.
[88] H. Clevers, "Modeling development and disease with organoids," Cell, vol. 165, no. 7, pp. 1586-1597, 2016.

[89] S. Bartfeld and H. Clevers, "Stem cell-derived organoids and their application for medical research and patient treatment," Journal of Molecular Medicine (Berlin, Germany), vol. 95, no. 7, pp. 729-738, 2017.

[90] M. A. Lancaster and J. A. Knoblich, "Organogenesis in a dish: modeling development and disease using organoid technologies," Science, vol. 345, no. 6194, p. 1247125, 2014.

[91] R. Morizane and J. V. Bonventre, "Kidney organoids: a translational journey," Trends in Molecular Medicine, vol. 23, no. 3, pp. 246-263, 2017.

[92] M. H. Little and A. N. Combes, "Kidney organoids: accurate models or fortunate accidents," Genes \& Development, vol. 33, no. 19-20, pp. 1319-1345, 2019.

[93] B. Phipson, P. X. Er, A. N. Combes et al., "Evaluation of variability in human kidney organoids," Nature Methods, vol. 16, no. 1, pp. 79-87, 2019.

[94] J. V. Bonventre, "Kidney organoids-a new tool for kidney therapeutic development," Kidney International, vol. 94, no. 6, pp. 1040-1042, 2018. 